\section{History, blood tests or skin prick testing? Is it possible to predict the severity of allergic reactions in children with IgE-mediated food allergy?}

\section{SCENARIO}

A 5 -year-old boy with a history of an itchy rash and lip swelling following peanut ingestion several weeks ago comes to see you in your outpatient clinic. His mother would like to know if her son will have a more severe reaction if he is exposed to nuts again. What advice do you give her and which, if any, investigations should be done?

\section{STRUCTURED CLINICAL QUESTION}

In a child with a history of an IgE-mediated allergic reaction to food (patient), are (intervention) blood tests, skin prick tests (SPTs) or the medical history helpful in determining the severity of future reactions (outcome)?

\section{Search strategy}

A Medline search 1946-2014 was performed, as per table 1. The same search terms were used for the Cochrane library, with nil relevant articles, and also for an Embase search which found one further original research paper. ${ }^{1}$ Anaphylaxis was searched separately as (predic* adj3 anaphyl*).mp in Embase, Cochrane and Medline, finding one new review article ${ }^{2}$ and one new original research article. ${ }^{3}$ Articles were excluded if they did not relate to food allergy or children.

The 16 original research articles included are summarised in table 2.

The findings of the relevant review articles ${ }^{2} 4-6$ and recommendations from the Royal College of Paediatrics and Child Health care pathway for food allergy ${ }^{7}$ and the National Institute for Health and Care Excellence (NICE) guidelines on food allergy in children and young people ${ }^{8}$ are discussed further in the Commentary section.

\section{COMMENTARY}

Immunoglobulin E (IgE)-mediated food allergy is common in children and is on the increase. ${ }^{8}$ There are studies that give a range of positive predictive values (PPVs) for SPT wheal size or specific IgE (sIgE) levels, aiming to help in diagnosis and reduce the need for food challenge in hospitals. ${ }^{23}$ The prediction of severity of allergic reactions is less studied and the NICE guidelines recommend further research in this area. 78

\section{Table 1 Medline 1946-2014}

\begin{tabular}{llr}
\hline 1 & exp *Food Hypersensitivityl & 11011 \\
2 & allerg*.ti,ab. & 132226 \\
3 & 1 or 2 & 134786 \\
4 & (predict* adj3 sever*).ti,ab. & 10216 \\
5 & 3 and 4 & 115 \\
& Keep & 14 \\
\hline
\end{tabular}

Historically accepted risk factors for severe allergic reactions are asthma, older age and a history of a previous severe reaction. These risk factors were accepted on the basis of older population-based data and case series of fatal anaphylaxis. ${ }^{5} 824$ 
Table 2 Summary of articles

Citation Study group

Study type

30 peanut allergic patients and 30 controls

$\begin{array}{ll} & 30 \text { pean } \\ \text { Astier et a }{ }^{9} & \text { controls }\end{array}$

Benhamou et al ${ }^{10}$

35 children attending clinic for diagnosis or follow-up of egg allerg

Calvani et al ${ }^{11}$

163 children with anaphylaxis to food (36 different foods, cow's milk most common) who completed a questionnaire.

Cianferoni et $a l^{12}$

983 children who underwent OFC to egg, milk and peanut 110 of whom developed anaphylaxis

\section{Clark and Ewan ${ }^{13} \quad 1000$ patients with a history of a} reaction to peanuts or tree nuts

Level 2

Cross-sectional observational study over 7 years

Hourihane et $a^{14} \quad 622$ self-reported peanut allergic questionnaire

Level 4

Case series.

Selection bias in further

evaluation of minority with skin prick testing and blood tests

Michaud et $a \beta^{3}$

98 peanut sensitised children divided into two groups depending on whether highly sensitized - slgE $>100$ or $\operatorname{slg} \mathrm{E}>12$

Neumann-Sunshine 782 children diagnosed with et $\mathrm{al}^{15}$ persistent peanut allergy, either on reaction (486 children) or high slg

Pourpak et al ${ }^{16}$ 24 patients with wheat allergy confirmed on the basis of history or positive OFC

cohort study, cons

Level 3 Retrospective cohort study, OFC

Level 4

Retrospective case-contro study

Level 3b

Retrospective case note

review

Level 4

Non-consecutive recruitment observational study, OFC

Outcome

Diagnostic value of 3

recombinant peanut allergens
Comparison of response and specific lgE levels

Clinical features in history associated with reaction type during anaphylaxis

Median slgE $2.47 \mathrm{kU} / \mathrm{L}(0.35-14.90)$ in mild and moderate and $3.7 \mathrm{kU} / \mathrm{L}(1.18-11.00)$ in severe reactions; $\mathrm{p}=0.006$

History of asthma increased risk of developing wheeze (OR 2.2, Cl 1.1 to 4.5). History of chronic $\mathrm{Gl}$ symptoms increased risk of vomiting (OR 2.1, 0.9 to 4.3 ), hypotension (OR $7.9,1.9$ to 32.0 ) and bradycardia/arrest (OR 9.2, CI 0.9 to 91.3 ). Future episodes similar severity in those patients with mild or moderate anaphylaxis

Comparison of severity of reaction Wheal size, prior non-cutaneous reaction (OR 4.2 to OFC with history, SPT, slgE with aim of trying to identify children at risk for a severe reaction on OFC

$\mathrm{p}<0.01$ ) and older age (OR 1.07, $\mathrm{p}<0.03$ ) associated with anaphylaxis.

Clinical significance of SPT and slgE results compared with history of reaction severity

Pattern of clinical severity of peanut allergy and symptom progression

Predictive factors for anaphylaxis more anaphylaxis $41.9 \%$ vs $28.8 \%$

Frequency of inadvertent peanut exposure, secondary outcome reaction severity

Comparison of history and slgE and SPT results

istory and slg

685 exposures studied. In 105 patients with initi for severe reaction; no association with age, sex and history of asthma and reaction severity

OR 14.4 for anaphylaxis in patients with slgE more

In 162 patients with brazil nut allergy, a history of severe reaction associated with larger SPT diameter, median 14 vs $10 \mathrm{~mm}$ in mild-moderate reactions, $p=0.0005$. No association for slgE or Asthma $(p=0.00013)$ and abdominal pain $(p<0.0001)$ associated with severe reaction Correlation with increased median wheal size and severe reactions $(p=0.04)$. No correlation with $s \mathrm{gE}$

\section{Key result}

Patients monosensitised to rAra $\mathrm{h} 2$ on SPT and

slgE have lower disease severity score (2 vs 3.5 ,

$p<0.02$ ) than patients polysensitised to rAra $h 1$, and/or 3 slgE $>100 \mathrm{kU/L}$, OR 3.44, (1.82 to 6.5$), p<0.001$ than $3+(>3.6 \mathrm{Ucs} / \mathrm{mL}) \mathrm{Cl} 1.36$ to 152.5

\section{Comments}

Authors report no correlation between the leve of slgE and severity of allergy but do not show data for this. Patients included were 3-20 years

Overlapping range between reaction severity groups

Severity of anaphylactic reaction broken down into five different types. 36 patients (22\%) had most severe form

Results used to develop a scoring system to predict anaphylaxis on OFC. 1 point for age $>5$ years, (PPV 70, NPV 60) reaction type (prior Gl, respiratory, multiorgan or anaphylaxis) SPT $>9 \mathrm{~mm}$, slgE $>5 \mathrm{kU} / \mathrm{L}$.

Overall, this score had an $80 \%$ specificity but only $44 \%$ sensitivity

Adults and children included, with severe symptoms more common in adults. Total lgE levels higher in teenagers

Conference abstract

A total of 159 children had two or more reactions. In these children with multiple reactions there was no significant change in severity with time.

$7.3 \%-10.8 \%$ postdiagnosis exposure per year Mean wheat-specific IgE was $73.8 \mathrm{Ucs} / \mathrm{mL}$ in patients with history of anaphylaxis and $24.8 \mathrm{Ucs} /$ $\mathrm{mL}$ in patients without anaphylaxis, $(p<0.02)$. No SD given 
Table 2 Continued

\begin{tabular}{|c|c|c|c|c|c|}
\hline Citation & Study group & Study type & Outcome & Key result & Comments \\
\hline Sahiner et al ${ }^{17}$ & $\begin{array}{l}167 \text { patients with history of food } \\
\text { allergy, divided into two groups: } 79 \\
\text { with anaphylaxis and } 88 \text { without and } \\
\text { compared with113 controls }\end{array}$ & $\begin{array}{l}\text { Level } 4 \\
\text { Case-control study }\end{array}$ & $\begin{array}{l}\text { Serum basal tryptase levels in the } \\
\text { groups }\end{array}$ & $\begin{array}{l}\text { Median basal tryptase higher in anaphylaxis } \\
\text { group: } 4 \mathrm{ng} / \mathrm{mL} \text { ( } 2.8-5.8 \text { ) anaphylaxis vs } 3.6 \mathrm{ng} / \mathrm{mL} \\
\text { (2.3-4.5) (allergy) vs } 3.3 \mathrm{ng} / \mathrm{mL}(2.4-4.4) \text { (control) } \\
\mathrm{p}=0.022\end{array}$ & $\begin{array}{l}\text { Tryptase }>14.5 \mathrm{ng} / \mathrm{mL} \text {. PPV } 90 \% \text { for severe } \\
\text { anaphylaxis, calculated via regression curve } \\
\text { analysis, only } 4 \text { patients in the study had a basal } \\
\text { tryptase }>11.4 \mathrm{ng} / \mathrm{mL}\end{array}$ \\
\hline Sicherer et $a l^{18}$ & $\begin{array}{l}5149 \text { children and adults in the USA } \\
\text { who were members of Food Allergy } \\
\text { and Anaphylaxis Network and } \\
\text { completed a questionnaire }\end{array}$ & $\begin{array}{l}\text { Level } 4 \\
\text { Voluntary database. } \\
\text { Selection bias present. } \\
\text { Self-reporting of allergy not } \\
\text { always accurate }\end{array}$ & $\begin{array}{l}\text { Characteristics of patients with } \\
\text { peanut and tree nut allergy }\end{array}$ & $\begin{array}{l}\text { Registrants } \\
\text { with asthma reported more severe reactions }(33 \% \\
\text { vs } 21 \% \text {; } p<0.0001) \text {. Subsequent reaction(s) more } \\
\text { severe than initial reaction and more likely to be } \\
\text { treated with adrenaline }(p<0.001)\end{array}$ & $\begin{array}{l}\text { Median age of registrant was } 5 \text { years, although } \\
\text { adults were also included in the database. } \\
\text { The first reaction was reported as a positive SPT } \\
\text { for peanuts by } 287 \text { registrants. This might } \\
\text { contribute to future reactions increasing in } \\
\text { severity }\end{array}$ \\
\hline Sicherer et a $\left.\right|^{19}$ & $\begin{array}{l}122 \text { children who completed a } \\
\text { questionnaire at review in US allergy } \\
\text { clinic with history of peanut or tree } \\
\text { nut allergy }\end{array}$ & $\begin{array}{l}\text { Level } 3 \mathrm{~b} \\
\text { Retrospective cohort study. } \\
\text { Unclear if consecutive } \\
\text { recruitment }\end{array}$ & $\begin{array}{l}\text { Clinical features following first } \\
\text { exposure and then any accidental } \\
\text { ingestion of nuts }\end{array}$ & $\begin{array}{l}\text { Majority had the same pattern of symptoms } \\
\text { following accidental exposure as at initial exposure }\end{array}$ & $\begin{array}{l}\text { Accidental exposure occurred in } 59 \text { patients with } \\
\text { following subsequent reactions: skin, } 44 \% \text {; } \\
\text { respiratory, } 10 \% ; \mathrm{GI}, 3 \% \text {; skin with respiratory, } \\
18 \% \text {; skin with } \mathrm{GI}, 8 \% \text {; GI with respiratory, } 2 \% \text {; } \\
\text { all three systems, } 15 \% \text {. One patient reported loss } \\
\text { of consciousness }\end{array}$ \\
\hline Spergel et $\left.a\right|^{20}$ & $\begin{array}{l}998 \text { food challenges in children with } \\
\text { suspected allergy to a range of foods }\end{array}$ & $\begin{array}{l}\text { Level } 3 \mathrm{~b} \\
\text { Retrospective review, OFC }\end{array}$ & $\begin{array}{l}\text { Does initial reaction predict future } \\
\text { reaction? }\end{array}$ & $\begin{array}{l}\text { Similar reaction to initial reaction on re-exposure } \\
\text { during OFC in most, but } 12 \% \text { of patients with } \\
\text { initial cutaneous reaction developed anaphylaxis } \\
\text { on OFC } \\
\text { No significant association of SPT and severe } \\
\text { reactions }\end{array}$ & \\
\hline Summers et $a l^{21}$ & $\begin{array}{l}1094 \text { patients with history of allergy } \\
\text { to peanuts and tree nuts seen in one } \\
\text { UK tertiary referral centre from } 1992 \\
\text { to } 2004 \text {. Clinical history of most } \\
\text { severe reaction analysed }\end{array}$ & $\begin{array}{l}\text { Level } 2 \\
\text { Consecutive recruitment, } \\
\text { cohort study }\end{array}$ & $\begin{array}{l}\text { Clinical features in history, total } \\
\text { lgE, specific lgE and serum ACE } \\
\text { levels }\end{array}$ & $\begin{array}{l}\text { Severe atopy, such as uncontrolled asthma, or } \\
\text { rhinitis was associated with severe reactions. In } \\
\text { severe rhinitis the OR was } 3.8 \text { ( } 2.1 \text { to } 6.9 \text { ) for } \\
\text { pharyngeal oedema. In severe asthma, OR for } \\
\text { bronchospasm was } 6.8 \text { ( } 4.1 \text { to } 11.3 \text { ). No } \\
\text { correlation with SPT and slgE and reaction severity }\end{array}$ & $\begin{array}{l}\text { Median age } 6 \text { years, but } 24 \% \text { participants were } \\
\text { adults. } \\
\text { Subgroup of } 122 \text { patients with sufficient serum } \\
\text { stored analysed for serum ACE levels. If low, then } \\
\text { there was a } 9.6 \text {-fold risk of severe pharyngeal } \\
\text { oedema, but there was likely selection bias in this } \\
\text { group }\end{array}$ \\
\hline Van Erp et al ${ }^{1}$ & $\begin{array}{l}225 \text { children sensitised to peanut on } \\
\text { slgE/SPT having DBPCFC, } 48 \% \text { no } \\
\text { previous reaction to peanut }\end{array}$ & $\begin{array}{l}\text { Level } 2 \\
\text { Retrospective review } \\
\text { DBPCFC used }\end{array}$ & $\begin{array}{l}\text { Are there risk factors in history or } \\
\text { SPT/slgE for positive and severe } \\
\text { food challenge outcome? }\end{array}$ & $\begin{array}{l}\text { No correlation for any predictors of positive food } \\
\text { challenge for more severe reactions }\end{array}$ & $\begin{array}{l}\text { Note children with history of ITU stay following } \\
\text { initial reaction excluded from study }\end{array}$ \\
\hline Wainstein et $a^{22}$ & $\begin{array}{l}89 \text { children referred for peanut } \\
\text { challenge. Protocol allowed for } \\
\text { challenge to continue despite mild } \\
\text { symptoms developing. Only } 55 \text { who } \\
\text { completed the OFC were included }\end{array}$ & $\begin{array}{l}\text { Level } 3 \\
\text { Prospective case-controlled } \\
\text { study with consecutive } \\
\text { recruitment. OFC ingesting } \\
\text { up to } 12 \mathrm{~g} \text { of peanut }\end{array}$ & $\begin{array}{l}\text { Comparison of response and } \\
\text { history, slgE and SPT results }\end{array}$ & $\begin{array}{l}\text { History of atopy and anaphylaxis not associated } \\
\text { with anaphylaxis in food challenge. } \\
\text { Higher mean wheal size }(10.2 \mathrm{~mm}(6.5-15.5) \text { vs } \\
6.7 \mathrm{~mm}(3-11.5), \mathrm{p}<0.0001) \text { and higher slgE in } \\
\text { anaphylaxis group }(20.5 \mathrm{kU} / \mathrm{L}(0.86->100) \text { vs } \\
0.68 \mathrm{kU} / \mathrm{L}(<0.37-8.5), \mathrm{p}<0.0001) \text {. }\end{array}$ & $\begin{array}{l}21 / 27 \text { peanut allergic children completing } \\
\text { challenge developed anaphylaxis on OFC ( } 78 \%) \text {. } \\
\text { Note } 40 \% \text { of children included had no history of } \\
\text { peanut reaction or ingestion and were included } \\
\text { as they were skin prick positive to peanut }\end{array}$ \\
\hline
\end{tabular}


The questionnaire-based population studies ${ }^{18-21}$ included in this study also support asthma as a risk factor for severe reactions. However, three studies looking at children undergoing food challenge 11222 show no difference in reaction severity for a history of asthma or other atopy. One explanation for conflicting results may lie in the different circumstances of the reactions, particularly the likelihood of the ingested dose of allergen on accidental exposure in the community being higher than in a typical food challenge. One study comparing allergic reactions in the community with double blind placebo-controlled food challenge (DBPCFC) finds only a weak association between reaction severity on DBPCFC and in the community. ${ }^{25}$ Furthermore, population studies include children with previous anaphylaxis, whereas most food challenge research ${ }^{5} 22$ excludes these children for safety reasons. Another factor to consider is that asthma is a common condition, reported in 50\% of children with food allergy by Spergel et al. ${ }^{20}$ So although the questionnaire-based population studies and analysis of fatal reactions show that severe reactions tend to occur in children with asthma, as asthma is so prevalent in children with food allergies, this also means that most food allergic children with asthma will not necessarily develop anaphylaxis. It is also important to note that there is significant variation in the severity of asthma and most research does not differentiate this. Summers et al, however, differentiated this variation and classified atopic children into severe or mild, depending on whether their symptoms were under control. They found that severe asthma gave a significantly increased relative risk (RR) of 6.8 for life-threatening bronchospasm in comparison with patients with milder asthma symptoms who had an RR of 2.7 for a severe reaction. ${ }^{21}$ This underlines the importance of achieving good asthma control in all children, particularly those with a diagnosed food allergy.

In terms of the importance of the history of reaction predicting future severity, Wainstein et $a l^{22}$ show no association between previous reactions and severity of the reaction during food challenge. This is the only study where the food challenge protocol allowed for further challenge doses despite onset of objective symptoms, as most other protocols stop at first onset of objective symptoms. There are limitations to this study such as lack of blinding and a small sample size. However, it is interesting to note that Wainstein $e t a l^{22}$ found that 21 of 27 children, or $78 \%$ of the children who completed the oral food challenge (OFC), developed anaphylaxis. This suggests that the dose of the allergen consumed is also important in determining the reaction severity. Other much larger studies ${ }^{12} 151920$ show a similar severity of reaction on re-exposure. Calvani et $a l^{11}$ found that the organ system affected in the initial allergy history correlated with the reaction type during acute anaphylaxis. Abdominal symptoms were associated with increased risk of collapse, a finding also noted by Hourihane et al. ${ }^{14}$ Spergel et $a l^{20}$ found that the overall most common reaction on OFC was cutaneous at $43 \%$, with anaphylaxis counting for $14 \%$ of reactions. A total of 218 children had a history of initial cutaneous reaction and 56\% of these children also had a further cutaneous reaction on OFC but $12 \%$ of children with an initial cutaneous reaction developed anaphylaxis on OFC, showing that a severe reaction is possible following any initial clinical presentation.

Most food challenge studies did not find that older age was significantly associated with reaction severity. ${ }^{10} 22$ Cianferoni et $a l^{12}$ found that age above 5 years had a PPV over 70 for anaphylaxis. Hourihane et $a l^{14}$ included adults and children and found more serious reactions in adults.
In 7 of the 11 studies reviewed above which looked at level of sIgE and/or SPT wheal size, a statistically significant correlation with severity of reaction was found. However, there is a wide range of results. For example, in Hourihane et $a l^{14}$ the range of SPT results in children with severe reactions $(4-15 \mathrm{~mm})$ is entirely within the range of those with mild reactions $(4-20 \mathrm{~mm})$. Three studies ${ }^{819} 20$ found no association and Clark et $a l^{13}$ found a significant association with SPT results in severe reactions to brazil nuts only. There is some limited quality data from both Michaud et $a l^{3}$ (level 4) and Neumann-Sunshine et $a l^{15}$ (level 3b) that highly sensitised children with $\operatorname{sgE}$ $>100 \mathrm{kU} / \mathrm{L}$ for peanut report more severe reactions. NeumannSunshine et al calculated an OR of 3.44 for anaphylaxis based on the reactions of 105 children with $\operatorname{sgE}>100 \mathrm{kU} / \mathrm{L}$. This suggests that children who are highly sensitised to peanuts are at higher risk for anaphylaxis. However, first, only a small proportion of children in the study are highly sensitised. Second, some children from this highly sensitised group do not go on to have severe reactions, whereas children with lower levels of sIgE do. ${ }^{15}$ Overall, despite associations of higher sIgE levels and higher SPT sizes with more severe reactions, the results are not of clinical significance for predicting future reaction severity in most children.

Component testing for sIgE to individual peanut proteins may be used in the diagnosis of food allergy to try to distinguish sensitisation from allergy with some success, although not necessarily with more accuracy than standard $\mathrm{SPT}^{26}$ Astier et al hypothesised that there may be a correlation between the components to which an individual is sensitised and the reaction severity. They found that patients monosensitised to rAra h 2 on SPT have a lower disease severity score than patients who are polysensitised to rAra h 2 and rAra h 1 and/or 3 in a casecontrol study. ${ }^{10}$ This is the only paper looking at disease severity score and sensitisation on SPT for peanut components. Other research shows no correlation with level of sIgE for Ara h 2 and disease severity score. ${ }^{27}$ As the molecular understanding of allergy increases, differentiating between allergen structures may become helpful in determining the severity of a food allergy in the future, although there is currently not enough evidence to support the use of component testing in predicting the severity of allergy.

Median basal tryptase levels were found to be higher in children with anaphylaxis in a case-control study (level 4 evidence) by Sahiner et al. ${ }^{17}$ However, there was significant overlap in levels between cases and controls and only four children had high tryptase levels, two of whom were non-allergic controls. There is currently not enough evidence that this test will help predict an individual's reaction severity.

In summary, although SPTs and blood tests may be useful in the diagnosis of food allergy, there are currently no tests that will accurately predict which children will go on to develop a severe allergic reaction.

Given the difficulty in predicting future reactions, it is important to educate families about food allergy. Some of the studies reviewed above rely on accidental exposure for their data on reaction severity and report high rates of postdiagnosis exposure, up to $50 \%$ over approximately a 5 -year period. ${ }^{15} 19$ Avoidance of food allergens is clearly difficult for children and their families. Following accidental exposure, only low numbers of patients $(34 \%)$ with severe reactions had adrenaline administered. ${ }^{15}$ Patient education is therefore the key clinical priority, as highlighted in a recent review on predicting reaction severity in peanut allergy. ${ }^{6}$ 


\section{Clinical bottom line}

- We cannot accurately predict which children with food allergy will have severe reactions in the future.

- The patient described above should have a thorough history taken and skin prick testing and specific immunoglobulin $\mathrm{E}$ testing, as per National Institute for Health and Care Excellence guidelines, to confirm the diagnosis.

- Following diagnosis of a food allergy, it is important to educate the family concerning allergy avoidance and management of accidental exposure.

\section{Lotte Harleman, ${ }^{1}$ Adrian $\mathrm{Sie}^{2}$}

${ }^{1}$ Royal Aberdeen Children's Hospital, Aberdeen, UK

'Wishaw General Hospital, Wishaw, UK

Correspondence to Dr Lotte Harleman, Royal Aberdeen Children's Hospital, ST5 Paediatrics, Westburn road, Aberdeen AB25 2ZG, UK; lotteharleman@hotmail.com, l.harleman@nhs.net

Acknowledgements We would like to thank Paul Manson, clinical librarian at NHS Grampian for his technical assistance with the literature search.

Contributors $\mathrm{LH}$ wrote the article originally as part of an assignment to do a literature review for the University of Glasgow Certificate in Child Health. AS was the supervisor for this review and developed the clinical question. He also reviewed and helped modify drafts of the article.

Competing interests None declared.

Provenance and peer review Not commissioned; internally peer reviewed.

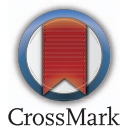

Received 10 December 2014

Accepted 10 April 2015

Arch Dis Child 2015;100:594-598. doi:10.1136/archdischild-2014-308046

\section{REFERENCES}

1 Van Erp FC, Knulst AC, Kentie PA, et al. Can we predict severe reactions during peanut challenges in children? Paediatr Allergy Immunol 2013;24:596-602.

2 Sicherer SH, Simons FE. Quandaries in prescribing an emergency action plan and self-injectable epinephrine for first-aid management of anaphylaxis in the community. J Allergy Clin Immunol 2005;115:575-8.

3 Michaud E, Pereira B, Labbe A, et al. Peanut serum specific lgE over $100 \mathrm{lU} / \mathrm{ml}$ : what does it mean? Allergy 2012;67:60 (Conference presentation).

4 Kim EH, Burks W. Managing food allergy in childhood. Curr Opin Paediat 2012;24:615-20.
5 Atkins D, Bock SA. Fatal anaphylaxis to foods: epidemiology, recognition and prevention. Curr Allergy Asthma Rep 2009;9:179-85.

6 Flinn A, Hourihane JO. Allergic reactions to peanuts: can we predict reaction severity in the wild? Curr Allergy Asthma Rep 2013:13:645-50.

7 Care pathway for food allergy. RCPCH website. Feb 2012. http://www.rcpch.ac.uk/ system/files/protected/page/2011_RCPCH-CarePathway-FoodAllergy_v6_(16.26).pdf.pdf

8 NICE guidelines on food allergy in children and young people: Diagnosis and assessment of food allergy in children and young people in primary care and community settings. Guideline CG 116. Feb 2011. http://guidance.nice.org.uk/ CG116

9 Astier C, Morriset M, Roitel O, et al. Predictive value of skin prick tests using recombinant allergens for diagnosis of peanut allergy. J Allergy Clin Immunol 2006;118:250-6.

10 Benhamou AH, Zamora SA, Eigenmann PA, et al. Correlation between specific immunoglobulin $\mathrm{E}$ levels and the severity of reactions in egg allergic patients. Pediatr Allergy Immunol 2008;19:173-9.

11 Calvani M, Cardinale F, Martelli A, et al. Risk factors for severe pediatric food anaphylaxis in Italy. Pediatr Allergy Immunol 2011;22:813-19.

12 Cianferoni A, Garrett JP, Naimi DR, et al. Predictive values for food challenge-induced severe reactions: development of a simple food challenge score. Israel Med Assoc J 2012;14:24-8.

13 Clark AT, Ewan PW. Interpretation of tests for nut allergy in one thousand patients, in relation to allergy or tolerance. Clin Exp Allergy 2003;33:1041-5.

14 Hourihane JO, Kilburn SA, Dean P, et al. Clinical characteristics of peanut allergy. Clin Exp Allergy 1997;27:634-9.

15 Neumann-Sunshine DL, Eckman JA, Keet CA, et al. The natural history of persistent peanut allergy. Ann Allergy Asthma Immunol 2011;108:326-31.

16 Pourpak Z, Mansouri M, Masdaghi M, et al. Wheat allergy: clinical and laboratory findings. Int Arch Aller Immunol 2004;133:168-71.

17 Sahiner UM, Yavuz ST, Buyuktiryaki B, et al. Serum basal tryptase may be a good marker for predicting the risk of anaphylaxis in children with food allergy. Allergy 2014;69:265-8

18 Sicherer SH, Furlong TJ, Munoz-Furlong A, et al. A voluntary registry for peanut and tree nut allergy: characteristics of the first 5149 registrants. J Allergy Clin Immunol 2001:108:128-32.

19 Sicherer SH, Burks AW, Sampson HA. Clinical features of acute allergic reactions to peanut and tree nuts in children. Pediatrics 1998;102e6.

20 Spergel JM, Beausoleil JL, Fiedler JM, et al. Correlation of initial food reactions to observed reactions on challenges. Ann Allergy Asthma Immunol 2004;92:217-24

21 Summers C, Pumphrey RS, Woods CN, et al. Factors predicting anaphylaxis to peanuts and tree nuts in patients referred to a specialist center. J Allergy Clin Immunol 2008;121:632-8.

22 Wainstein BK Studdert J, Ziegler M, et al. Prediction of anaphylaxis during peanut food challenge: usefulness of the peanut skin prick test (SPT) and specific lgE level. Pediatr Allergy Immunol 2010;21:603-11.

23 Peters RL, Gurrin LC, Allen KJ. The predictive value of skin prick testing for challenge-proven food allergy: a systematic review. Pediatr Allergy Immunol 2012;23:347-52.

24 Pumphrey R. Fatal anaphylaxis in the UK. Novartis Found Symp 2004;257:116-28.

25 Hourihane JO, Grimshaw KE, Lewis SE, et al. Does severity of low-dose, double blind placebo-controlled food challenges reflect severity of allergic reactions to peanut in the community? Clin Exp Allergy 2005;35:1227-33.

26 Dang TD, Tang M, Choo S, et al. Increasing the accuracy of peanut allergy diagnosis by using Ara h 2. J Allergy Clin Immunol 2012;129:1056-63.

27 Blumchen K, Beder A, Beschorner J, et al. Modified oral food challenge used with sensitization biomarkers provides more real-life clinical thresholds for peanut allergy. J Allergy Clin Immunol 2014;134:390-8. 